\title{
Swedish Employers and Trade Unions, Labor Migration and the Welfare State-Perspectives on Swedish Labor Migration Policy Debates during the 1960s and the 2000s
}

\section{Jesper Johansson}

Senior lecturer in social work, Department of Social Work, Linnaeus University, Växjö, Sweden ${ }^{1}$

\begin{abstract}
This article uses a political economy approach and explores the nexus between labor migration and the welfare state and how its specificities have been viewed and presented by organized interests of employers and trade unions in Swedish labor migration policy debates during the 1960s and the 2000s. The analysis demonstrates that the Swedish Employers' Confederation (SAF) and its organizational successor the Swedish Confederation of Enterprise (SN) have preferred a market-liberal labor migration policy. Over time, a liberal immigration policy has been viewed by employers as an important policy solution to extend levels of economic growth, increase firm competitiveness, and maintain funding for generous welfare state services. However, since the 1960s the Swedish Trade Union Confederation (LO) has preferred a state-coordinated and regulated labor migration policy. In LO's perspective, a regulated immigration policy is a fundamental precondition for guaranteeing workers' rights, and for minimizing potential negative effects for the functioning of the Swedish labor market model and for a prosperous Swedish welfare state.
\end{abstract}

\section{KEY WORDS}

Labor migration policy / LO / organized interests / SAF / SN / welfare state

\section{Introduction}

rom the perspective of political economy migration politics and policy are fundamentally about interests (Freeman, 1986, 2004). Against the backdrop of an ageing population, in Sweden and other European countries, relevant actors with an interest in migration policymaking "have become aware of how a sharp rise in the number of those exiting the labor market, particularly retirees who require increased access to costly social service, may necessitate labor migration," as Gregg Bucken-Knapp stresses (Bucken-Knapp, 2009: 34; cf. Lundqvist, 2002). Hence, especially organized interests on the labor market are actors that are involved in migration policymaking, and which look upon the nexus between migration and the welfare state as a crucial issue when they formulate their migration policy preferences.

However, debate on the impacts of labor migration for the welfare state is not only a contemporary phenomenon in Sweden. Labor migration became increasingly debated in the mid-1960s, leading to regulation and an eventual stopping of labor migration from outside the Nordic countries in 1972. Although refugee migration and family reunification has dominated immigration figures since then, the door has since 2008

\footnotetext{
${ }^{1}$ E-mail: jesper.johansson@lnu.se
} 
been opened to large-scale labor migration from outside the EU due to a liberalization of Swedish labor migration polices. ${ }^{1}$ The article deals specifically with debates about labor migration where potential labor migrants need work and residence permits for immigration. Consequently, the common Nordic labor market since 1954 and Sweden's EU membership since 1994 and the consequences regarding intra-Nordic and intra-EU migration policy will not be dealt with.

By using a political economy approach, this article aims to explore the nexus between labor migration and the welfare state and how its specificities have been viewed and presented by Swedish Employers' Confederation (SAF), Swedish Confederation of Enterprise (SN) (the organizational successor to SAF), and Swedish Trade Union Confederation (LO) in Swedish labor migration policy debates during the 1960s and the 2000s.

The study is delimited to the three central confederations: SAF, SN, and LO. Since these organizations have been deeply involved in Swedish labor migration policymaking during both historical periods investigated, they have been selected as relevant actors to study. SAF and SN have been the dominant and influential employer organizations in Swedish enterprise and concerning labor market policymaking in general, and labor migration policymaking in specific (Waara, 2012: 13-14). Regarding the positions of trade unions, labor migration mostly concerned labor market sectors of blue collar workers and trade unions organized within LO during the 1960s. The Swedish Confederation for Professional Employees (TCO) and the Swedish Confederation of Professional Associations (SACO) were not much involved in labor migration policymaking during this period as a consequence of these structural circumstances (cf. Johansson, 2008; Lundqvist, 2002). Due to changes in the overall structure of the labor market with the expansion of the service economy and the decline of manufacturing, employers in various labor market sectors as information technology, certain health services, and universities have demanded and recruited skilled migrant workers during the 2000s (cf. Cavidies, 2010: 4-5). Consequently, TCO and SACO have become more engaged in debates about labor migration policymaking during this period. Nevertheless, LO has also continued to be sincerely involved in policymaking and public debates concerning labor migration, since the recruitment of migrant workers to labor market sectors of blue collar workers once again became intensely debated in Sweden during the 2000s (cf. Bucken-Knapp, 2009; Yalcin, 2010). Since LO is the trade union confederation involved in both historical labor migration policy debates of interest in the study, it is possible to analyze its policy preferences over time. However, TCO and SACO are not studied due to their marginal involvement in Swedish labor migration policy debate during the 1960s.

Moreover, since I focus on the three central confederations, the activities and preferences of SAF, SN, and LO member organizations are given less attention. Likely there have existed different opinions within the central confederations concerning different issues, but in this study I am interested to illuminate the official policy preferences of SAF, $\mathrm{SN}$, and LO. The following research questions will be investigated:

- How have Swedish employers and trade unions viewed and presented the connections between labor migration and the functioning of the Swedish welfare state?

- What have been the policy preferences of SAF, SN, and LO regarding granting new labor migrants full or restricted access to the Swedish welfare state?

- What similarities and differences could be identified over time concerning the social partners' positions on these issues? 


\section{The Swedish case of organized interests and labor migration policy debate: analytical perspectives}

I adopt analytical perspectives influenced by theories in political economy and by previous work concerning the role of organized interests in migration studies (cf. Cavidies, 2010; Freeman, 1986, 2004; Menz, 2008; Penninx \& Roosblad, 2000; Svanberg, 2011). A point of departure, influenced by this body of research, is that labor market organizations have interests to protect. On the one hand, trade unions can view labor migration as a potential labor market threat that will undermine the unions' relative power position in relation to the employers (Penninx \& Roosblad, 2000: 4). From this perspective, it can be seen as rational from the trade unions' point of view to oppose immigration of migrant workers. The historian Klas Åmark argues that restrictive practices regarding the supply of labor is one important strategy unions use to avoid wage dumping, and it is used as a tool in their try to defend their members' interests (Åmark, 1986: 20). On the other hand, trade unions can realize that increased supply of labor may be in the interest of their members as labor migration could contribute to expanded production and increased economic growth and welfare in the country (Penninx \& Roosblad, 2000: 4). From this perspective, employer organizations and trade unions can have coincided interests concerning labor migration. Employers' organizations are eager to increase the labor supply, so that production can continue undisturbed, and trade unionists realize the great contribution of the migrant workers to the growth rate, which the trade union members also benefit from (Penninx \& Roosblad, 2000: 4; Svanberg, 2011: 94). Therefore, one analytical focus of the article is to identify coincided and disparate interests between SAF, SN, and LO concerning labor migration in relation to the Swedish labor market and the welfare state.

In Sweden, the national employer and trade union organizations have played a key role since the early 1900s in developing institutions and policies for the labor market, and also for that matter to large areas of the welfare state. The original meaning of the concept "Swedish model" related to capital-labor cooperation and to the peaceful development of the labor market during post-World War II period. The state, however, also came to play an important role in relation to organized interests of employers and trade unions and labor market policymaking in the shape of a national agency, the Labor Market Board (AMS), in the late 1940s (Åmark, 1992: 432; Lundqvist, 2006: 185-186). When it comes to the question of defending interests, the access of employers' organizations and trade unions to government and their integration in policymaking is crucial (cf. Cavidies, 2010; Menz, 2008). Swedish employers and trade unions have been involved in decision-making and implementation of public policies in a broad scale of policy fields through the long tradition of social partnership and tripartite policymaking, particularly between the 1930s and the 1980s (Hermansson, 1993; Lewin, 1992). Concepts such as corporatism and neocorporatism are also used to refer to these institutional structures of policymaking, where interest groups are involved in the political process (cf. Williamson, 1989). During the last couple of decades, corporatism in Sweden has declined (Hermansson et al., 1999; Lindvall \& Sebring, 2006).

This article presents one national case of labor migration policy debates between organized interests of employers and trade unions. Previous studies about social partner debates in Europe concerning a liberalization of restrictive labor migration policies have mostly focused on countries representing liberal and conservative welfare 
states (cf. Cavidies, 2010; Menz, 2008). This study complements these previous studies by focusing on Sweden, a national case often characterized as representing a role model of a social democratic welfare regime (cf. Esping-Andersen, 1990). According to Esping-Andersen, characteristic of welfare states representing the social democratic welfare regime are:

a mix of highly de-commodifying and universalistic programs that, nonetheless, are tailored to differentiated expectations. Thus, manual workers come to enjoy rights identical to those of salaried white-collared employees or civil servants; all strata are incorporated under one universal insurance system, yet benefits are graduated according to accustomed earnings. This model crowds out the market, and consequently constructs an essential universal solidarity in favour of the welfare state. All benefit; all are dependent; and all will presumably feel obliged to pay. (Esping-Andersen, 1990: 28)

This study will provide theoretical as well as empirical examples from the Swedish case about how specific, liberalized labor migration policy reform proposals may be a challenge to welfare state principles of universalism (cf. Bucken-Knapp, 2009: 36-37).

Furthermore, theoretically I lean on research, arguing that there exist possible tensions between labor migration and the welfare state (cf. Banting, 2000; BuckenKnapp, 2009; Freeman, 1986). By doing an empirical study of the Swedish case, I contribute to this body of research by exploring if and how these arguments and claims have been at the center of the Swedish labor migration policy debates as well. Moreover, the debates about labor migration between the social partners in Sweden underscore how key arguments concerning welfare state challenges to a large extent are sketched out on the basis of a perceived organizational interest in relation to the labor market.

In Swedish migration and labor market research there exist a parcel of important studies conducted on trade union strategies and views in relation to labor migration during the postwar period (Johansson 2008, 2013; Lundh, 1994; Lundqvist, 2002, 2006; Nelhans, 1973; Svanberg, 2010, 2011; Yalcin, 2010). These studies have stressed the important function which LO and Swedish Metalworkers' Union have had in Swedish labor migration policymaking from the early post-world war years in the late 1940s until the 2000s.

Except from Joacim Waara's (2012) study about SAF and its strategies about labor migration between 1945 and 1972, there is a lack of studies about Swedish employers' organizations and their migration policy preferences, especially during the contemporary period of the 2000s. The connections between the social partners' migration policy preferences and the welfare state have also been given little scholarly attention. One exception is Gregg Bucken-Knapp $(2007,2009)$ which touches on these issues in his studies about the development of the Swedish Social Democratic Labor Party (SAP) and LO's labor migration policy preferences prior to the reform of Swedish labor migration policy from non-EU/EES countries in late 2008. Frida Boräng's study National Institutions-International Migration (2012) stresses that generous and universal welfare state institutions affect norms and values, and therefore they have a positive impact regarding admissions of forced immigrants of refugees and asylum seekers. Boräng's study concludes that national institutions like the welfare state are of importance for immigration policies. However, her study focuses the causal mechanism concerning the 
welfare state and forced immigration of refugees and asylum seekers, and not the relationship concerning labor migration, organized interests, and the welfare state like this study concerns. By combining a relational perspective, with a focus on both the social partners, and a historical perspective, this study illuminates the labor migration policy preferences of Swedish employers' organizations and trade unions in two different historical contexts and its continuities and changes over time. Accordingly this study, with its relational perspective and historical research focus on continuity and change, differs from and complements previous research about Swedish organized interests and labor migration policy and politics.

The analysis of the labor migration policy debate during the 1960 s is primarily based on secondary sources, and the material consists of important previous studies regarding LO's and SAF's labor migration policy preferences during that time period. The analysis of the debate during the 2000s relies on organizational reports and proposals from $\mathrm{SN}$ and $\mathrm{LO}$, interviews with two representatives of $\mathrm{SN}$, state-commissioned reports, and secondary sources (mainly policy analysis of Swedish labor migration policy). The selected organizational reports have been chosen as they are representative of SN's and LO's official policy preferences. As the reports are of a political and arguing character, they have been approached by using a contextualizing, ideology-critical method, where the aim is to identify and analyze political arguments in relation to the surrounding social context of the text (Thompson, 1984). Mainly, as mentioned above, when analyzing the reports I have focused on identifying coincided and disparate interests between SN and LO regarding labor migration in relation to the Swedish labor market and the welfare state. Furthermore, two interviews have been conducted with two representatives of $\mathrm{SN}$, which both have authored two separate $\mathrm{SN}$ reports. The aim was to collect complementing information to the written reports regarding SN's standpoints about labor migrants' social rights.

\section{Migration/welfare state nexus, organized interests, and labor migration policy preferences}

While migration may be one means to resolve the funding and labor shortage problems confronting advanced welfare states, it also creates challenges. Gary Freeman (1986) argues that migrant workers are not just pulled to employment opportunities in receiving countries in a search for high direct wages paid by the employer, but also for wide-ranging indirect wages, of state-provided benefits, protections, and rights which "is part of the package of compensation that exerts an attractive pull on workers in less prosperous societies" (Freeman, 1986: 55). Freeman stresses that welfare states may adopt restrictive migration policies to protect the welfare state budget, but also that welfare state services and benefits to indigenous workers "helps set in train the sequence of events that creates the demand of the receiving countries for migrant labor in the first place" (Freeman, 1986: 55). One of Freeman's basic arguments is that the financial basis of the welfare state may be challenged when unrestricted labor migration is combined with full access to welfare state benefits (cf. Bucken-Knapp, 2009).

Against this backdrop of welfare state challenges produced by migration, as presented by Freeman, it is reasonable to assume that tensions between migration and the welfare state are also grounded in the reactions of majorities, which may lead to specific 
policy preferences by actors and institutions in receiving immigration countries. Keith G. Banting (2000) has used the concept of "welfare chauvinism" to describe the restrictive preferences held by groups that have traditionally supported the welfare state but opposes "open immigration policies and the ready access of foreigners to social benefits" (Banting, 2000: 22). According to Banting, welfare chauvinism can take two forms: either restrictive benefits policy, "designed to deny resident foreigners access to social benefits" at the same conditions as the citizen population; or restrictive immigration policy, "designed to prevent foreigners coming into the country and having access to comprehensive social programmes" (Banting, 2000: 22-23, 23 quotation). According to Banting, it is the second form of welfare chauvinism that has had the most significance in "expansive welfare states." He comments the fact that countries which established a strong social regime, whether of social democratic or corporatist-subsidiarity complexion, have been generally successful at incorporating those migrants who have been granted legal residence. The price to be paid has been the acceptance of restrictive immigration policies (Banting, 2000: 25). Hence, an assumption in Banting's study is that restrictive immigration policies are of importance in advanced welfare states to protect their advantaged financial status of the welfare state. However, as also noted by Gregg Bucken-Knapp (2009: 36), in many social democratic welfare states restrictive benefits policy have not been "the policy instrument of choice." Instead they have combined a generous social policy with a restrictive immigration policy.

As further argued by Bucken-Knapp, proposals linking liberalized immigration policies "to limited or graduated access to social services constitute an additional challenge to social democratic welfare states" (Bucken-Knapp, 2009: 36). By citing Esping-Andersen's work on welfare state regimes and the principles of universalism as defining features of the Scandinavian welfare states, Bucken-Knapp stresses that it is chiefly the principles of universalism, and not primarily the financial basis of the welfare state, that come "under assault" by proposals of liberal immigration policy combined with restrictive benefits policy. According to Bucken-Knapp, the question of "boundary lines in terms of those who do and do not deserve state-funded provision of social services" is a crucial issue for why the given migration policy preferences "may challenge welfare state principles of universalism" (Bucken-Knapp, 2009: 36).

As argued by Bucken-Knapp the question of boundary lines regarding allocation of welfare state benefits and services becomes more complex in relation to migration, and particularly "when taking into account that not all residents of the welfare state are citizens" (Bucken-Knapp, 2009: 36). Yet, the Scandinavian welfare states have tended to define the principle of universalism in an inclusive manner, granting legal migrants access to a package of social benefits and services. As further noted by Bucken-Knapp, proposals for migration policy reform that contain requirements "limiting migrant access to social services, or phasing them in over time" are at odds with the principle of universalism, and in many ways "reintroduce the thorny issue of where appropriate welfare state boundary lines ought to be drawn" (Bucken-Knapp, 2009: 37).

Accordingly, as stressed by Freeman (1986) and Bucken-Knapp (2009), unregulated labor migration has the potential to threaten the financial and service capacity of the welfare state, and as a consequence undermine the welfare state system that migrant labor is intended to help maintain in the first place. 


\section{Trade union requests for a regulated immigration policy during the 1960s}

In the 1950s there were on average 100,000 migrants working in Sweden. During 1960s the numbers increased extensively, to more than 200,000 foreign-born workers in 1970 (Svanberg, 2011: 92). During this time period, the Finns were the largest migrant group in the country, an increase from 45,000 in 1950 to 191,000 in 1970. The second largest migrant group was Yugoslavians, an increase from none in 1950 to 34,000 in 1970. Other large groups were Germans (about 20,000), Danes (23,000 in 1950 and 16,000 in 1970), Norwegians (31,000 in 1950 and 13,000 in 1970) and Greeks (none in 1950 and 12,000 in 1970) (Spång, 2009: 17).

In the 1950s, Sweden's immigration policy in many ways became liberalized compared to the more restrictive policies during the interwar period and the early postWorld War years in the late 1940s. The 1954 Aliens Act made free movement a central principal, but it was also stipulated that this principle needed to be viewed in relation to the surrounding context of social and economic circumstances. Moreover, the law "stipulated that the government had the authority to issue regulations concerning visa, residence and work permits and the like in the Aliens Ordinance" (Spång, 2009: 76-77, 77 quotation). The period between the new Aliens Act 1954 and the mid-1960s was a period of liberal immigration policy. Although both the Swedish government and the state authorities favored state-coordinated labor migration through collective recruitment or company recruitment of labor under government regulation via AMS, individual immigration dominated during this period. This category of immigration was dominated by Nordic citizens, especially Finnish citizens, entering Sweden via the joint Nordic labor market. ${ }^{2}$ Moreover, in the late 1950s and during the 1960s large groups of individual migrants came to Sweden from other European countries on tourist visas, looked for employment, and then applied for a work permit, which was usually granted (Lundqvist, 2002: 114-115; Spång, 2009: 77).

The liberal immigration policy became challenged by LO during the 1960s, although the organization had already argued that labor market policies primarily should focus on domestic labor reserves, as married women, elderly, and "partially disabled" persons. However, the competition between this trade union policy preference for domestic labor reserves and the demand for sufficient labor in a context of economic growth and expansion had not been pushed by LO, which until the mid-1960s accepted labor migration. The trade unions accepted that industrial growth and the expansion of the Swedish welfare state were dependent on the labor supply. The trade union movement was prepared to let labor migration help out with bottlenecks in the production process (Johansson, 2008: 122-133; Lundh, 1994: 25-28; Spång, 2009: 77). From that perspective the interests of LO and SAF coincided regarding their views about the need for labor migration.

Yet, during the 1960s LO started to focus on what it perceived to be fundamental labor market and social problems related to unregulated labor migration. The increase in the number of labor migrants coming to Sweden in the mid-1960s provided an important background as to why LO became more critical at this point of time. For instance, the number of labor migrants from Yugoslavia, Greece, and Turkey arriving in Sweden on tourist visas increased greatly between 1964 and 1967, nearly doubling compared to figures between 1960 and 1964. The increased immigration and the subsequent 
communication and language problems on the shop floors contributed to debate within the trade union movement about the economic and social consequences of labor migration (Johansson, 2008: 170-171; Lundh, 1994: 25-28; cf. Yalcin, 2010). ${ }^{3}$

Both LO and SAP highlighted that the liberal immigration policy, in place since 1954, threatened wage levels for Swedish workers. LO officials argued against a situation where those employers who avoided the payment of higher wages could instead recruit migrant workers with the help of AMS and a liberal immigration policy (Bucken-Knapp, 2007: 9). In LO's opposition to the liberal immigration policy, the discussions focused on how an unregulated labor migration could threaten central features of Swedish labor market policies and delay labor market access for groups as married women, elderly, and "partially disabled" persons. LO argued that the recruitment of migrant workers, "particularly to low-wage sectors," could delay structural transformations within these industries and "thereby counteract policies whose purpose was to improve the positions of low-wage workers” (Bucken-Knapp, 2007: 9; cf. Johansson, 2008: 149-151; Lundh, 1994: 26-30). Another concern within LO was that competition between migrant and indigenous workers for insufficient housing in regions with labor shortages would destabilize policies to increase the mobility of the indigenous workforce. A further potential negative aspect of continued unregulated labor migration was also noted, "as it was argued that labor migrants were more likely to place greater overall strain on societal resources than would domestic groups" (Bucken-Knapp, 2007: 9; cf. Johansson, 2008: 149-151; Lundh, 1994: 26-30). As a consequence of these trade union concerns, LO argued that non-Nordic labor migration should take place under regulated and organized forms. Its main argument was that immigration should be "adapted" to the ups and downs of the labor market and with consideration for the potential of Swedish society to take good care of its new citizens and give them equal social conditions as indigenous Swedes regarding employment, housing, education, and social benefits. Furthermore, LO thought that these problems and risks related to unregulated labor migration consisted a threat to universal welfare state ambitions. Hence, a regulated immigration policy was presented as a necessary prerequisite to provide good conditions for facilitating what was labeled as the "adaptation" of immigrants to the Swedish society (Johansson, 2008; 149-151; Lundh, 1994: 26-30; cf. Yalcin, 2010). As argued by Torbjörn Lundqvist, LO wanted to "avoid the emergence of a migrant worker reserve living under the threat of unemployment and reducing pay and benefit levels in Swedish working life" (Lundqvist, 2006: 192), and moreover LO preferred to evade an increased migrant dependency in relation to the welfare state.

\section{Employer preferences-continued liberal immigration policy}

The employer organization SAF did not agree with LO's argumentation concerning problems related to labor migration. SAF rejected LO's request about a regulation of the non-Nordic immigration. SAF argued for a continued liberal immigration policy, due to the reasoning that immigration tended to follow the ups and downs on the labor market. In SAF's point of view, immigration had a long-term, self-regulating dimension in relation to the economic and labor market situation. Furthermore, SAF opposed LO's arguments that immigration tended to increase competition between indigenous and migrant workers, and that immigration could have a negative impact on the possibilities 
of providing labor market access for indigenous labor reserves. Therefore, as a consequence of this reasoning, according to SAF there was no reason for a resumption of a regulated immigration policy (Waara, 2012: 124-125, 130-131).

SAF also objected to LO's description of labor market and social problems as related to labor migration. According to SAF there was no such trend that labor migrants were exploited on the labor market. Statistics showed that immigrants were not concentrated to low-paid industries and sectors, but were to be found in a wide range of occupations and sectors. Approximately $25 \%$ of the migrant workers in Sweden were for instance working in the engineering sector, which was an industrial sector with rather high wages, although SAF admitted that immigrants tended to be allocated the least attractive occupations and assignments, due to the fact that the indigenous workers have left them in the context of labor shortages. Yet, according to SAF this was not synonymous with low wages, and SAF demonstrated this reasoning by recalling the fact that many migrant workers were working in the mining industry, which was an industry with middle-high wages, but with inconvenient working environment and working hours (Waara, 2012: 125-126). In relation to the trade union critique that immigrants were discriminated on the housing market, SAF rather expressed the view that the problems with housing shortages were not a specific problem related to immigration, but rather a general problem that coincided with Swedish companies' hiring of new workers, and irrespective of workers migrating within Sweden or from a foreign country to Sweden. According to SAF, LO used the argument about housing shortages as an excuse to oppose further immigration, without acknowledging general housing shortages in the Swedish society (Waara, 2012: 127-128).

Since SAF had the view that immigration followed the ups and downs on the labor market, and was self-regulating, the employers did not share LO's concern about the risks of increased economic and social costs for the Swedish welfare state as a consequence of immigration, in terms of increased costs for unemployment, housing, schools, and other social benefits. Hence, SAF's argumentation was based on the assumption that immigrants contributed to economic and industrial growth and public revenue in Sweden through their work under the circumstances with an economic boom and perceived labor shortages. Nevertheless, according to SAF, if immigrants would have troubles to find employment opportunities, they would likely migrate to another country or reemigrate to their home countries. Except this reasoning, as showed by Joacim Waara, SAF did not engage further into discussions about possible problems and costs for Swedish society in relation to immigration (Waara, 2012: 130). Without taking a stand on whether SAF actually did not perceive any problems, or did not want to perceive any, the argumentation of the employers suited their preferences for a market-liberal immigration policy, while the opposite is true for LO's argumentation based on a disparate trade union interest in favor of a regulated immigration policy.

\section{Regulation of non-Nordic labor immigration in 1966-1972}

LO's concern about unregulated immigration led to negotiations between LO, SAF, AMS, and the Ministry of Interior during summer and autumn 1965. SAF opposed any policy changes, and argued in favor of a liberal immigration policy, but LO and AMS preferred regulations and the SAP government followed their recommendations (Lundh, 1994: 
27-28; Waara, 2012: 132-136). The first policy change in January 1966 was implemented to prevent individual non-Nordic immigration that had been common under tourist visas. A system of collective recruitment of labor was reintroduced and AMS was given the mandate to manage and be responsible for that system. ${ }^{4}$ Migrant workers arriving to Sweden through the AMS system were required to have a work permit before entering the country. These regulations had to be supplemented a year later due to the fact that exceptions to the rules meant that large numbers of non-Nordic immigrants seeking employment continued to arrive to Sweden under tourist visas. The second policy change was implemented in March 1967, and this regulation stated that the authorities should not give work permits to individuals coming to Sweden on their own initiative. The rules mandated that non-Nordic migrant workers should have an employment offer, a work permit, and housing arranged before entering Sweden (Bucken-Knapp, 2009: 53-54; Lundh, 1994: 28-30; Spång, 2009: 77-78).

According to Mikael Spång (2009: 78), neither the 1966 nor the 1967 regulations were debated in the Swedish parliament, but were decided by the Swedish SAP government. Yet, the policy changes were confirmed by the parliament. Parallel to the policy regulations in 1966 and 1967, a parliamentary commission analyzed several immigration policy issues and presented its results and suggestions in 1967. The commission argued that the Swedish parliament and government needed to implement a more comprehensive immigration policy (SOU 1967: 18; Spång, 2009: 78).

Indeed, it is striking how LO influenced other central actors like AMS and SAP in this policy reform process, and LO's influence over Swedish immigration policy has been emphasized by different scholars (cf. Frank, 2005; Hammar, 1988; Johansson, 2008, 2013; Knocke, 2000; Kyle, 1979; Waara, 2012; Yalcin, 2010). In many ways LO and the trade union movement drove these reforms of immigration policies during the 1960s. Accordingly, LO's influential position is demonstrated by the fact that much of LO's argumentation regarding the negative effects of unregulated labor migration on Swedish labor market and social policies was also present in the parliamentary report in 1967 and in the SAP government's proposition in 1968 that manifested the policy shift in favor of a regulated and state-coordinated immigration policy (Regeringens proposition, 1968: 142 [Government proposition]; SOU 1967: 18). The SAP government did not pay the same attention to SAF's protests against these regulations, and the government did not agree with the employer's standpoint that Sweden should stick to a liberal and market-driven immigration policy (Waara, 2012).

The regulations between 1966 and 1968 led to increased control of labor migration from outside the Nordic countries. However, the end of large-scale labor migration is usually dated to 1972, when LO in an internal circular recommended national and local unions to be restrictive regarding approval of work permits for non-Nordic labor migrants (Hammar, 1988: 11-14; Spång, 2009: 79). LO’s standpoint and strategy in 1972 could be seen against the backdrop of the recession in 1971-1972, but also in relation to its prioritization of the domestic labor reserves at the expense of further labor immigration in case of future increase in the demand for labor (Johansson, 2008: 207-212; Spång, 2009: 79; Yalcin, 2010: 155-162).

Indeed, the close relationship between LO, SAP, and AMS and the administrative system surrounding the decision-making process of work permits is an important institutional factor, which is central to understand LO's and the trade union movement's influence over the immigration of labor, not only in relation to the regulations in 1966-1968 and 
1972, but during the entire postwar period. Local trade unions were consulted by AMS and the local labor market board, and the unions could approve or reject individual applicants from non-Nordic countries. Parallel to these local administrative procedures, the national trade unions or LO had either consultative status to labor market authorities or direct representation in decision-making bodies (cf. Frank, 2005; Hammar, 1988; Knocke, 2000; Kyle, 1979; Svanberg, 2010; Waara, 2012; Yalcin, 2010). With the immigration policy regulations of 1967-1968, LO also received the more regulated immigration practices governing the admission of non-Nordic labor migrants as the trade union movement had requested during the 1960s. LO's preferences of restrictive immigration practices relates to the basic trade union interest to restrict the total labor supply in defense of the trade union members economic and social positions.

Thus, the employer and trade union preferences and interests concerning Swedish labor migration policy were to be debated again in a later historical context.

\section{SN's calls for market-liberal labor migration policy in the 2000 s}

As regards Sweden and the immigration structure in the early 2000s, figures from the Swedish Migration Board show that between 2000 and 2004, 116,330 (47\%) permanent residence permits were granted for family reunion reasons; 39,580 (17\%) went to refugees. Accordingly, almost 156,000 individuals (64\%) received a permanent residence permit, primarily not on grounds related to labor market or education. A total of 1,806 individuals $(1 \%)$ from non-European countries were granted a permanent residence permit for labor market reasons. Additionally, a substantial share of individuals receiving a permanent residence permit due to EU/EES agreements arrived in Sweden primarily for labor market reasons.

Table I Permanent residence permits granted in Sweden 2000-2004.

\begin{tabular}{lcc}
\hline Reasons & Numbers & Share (\%) \\
\hline Relatives & 96,208 & 40 \\
\hline EU/EES & 46,408 & 23 \\
\hline Refugees & 39,580 & 17 \\
\hline Guest students & 23,177 & 10 \\
\hline Relatives of refugees & 20,122 & 7 \\
\hline Children of adoption & 4,110 & 2 \\
\hline Labor market reasons & I,806 & 1 \\
\hline In total & $\mathbf{2 3 1 , 4 1 \mathbf { I }}$ & $\mathbf{1 0 0}$ \\
\hline
\end{tabular}

Source: Figures from the Swedish Migration Board (SOU 2005: 50: 112 ).

In the early 2000s the Swedish migration policy that governed labor migration from non-EU countries could be characterized as state-coordinated and restrictive. According to Bucken-Knapp (2009: 56), non-EU citizens could almost only migrate to Sweden for purposes of employment in order to fill "short-term labor market gaps." Less than an 
average of 8,000 non-EU migrant workers were admitted per year on temporary permits between 2000 and 2004 (Bucken-Knapp, 2009: 56).

However, in late 2008, the Swedish parliament adopted a proposition (Regeringens proposition 2007/08: 147 [Government proposition]) from the bourgeois government concerning a market-liberal policy to non-EU labor migration, allowing employers to determine whether non-EU citizens should be allowed to migrate for purposes of employment (Riksdagens protokoll 2008/09: 26 [Parliament record]). This Swedish labor migration policy change in 2008 was preceded by a policy debate between the social partners. From the early 2000s until late 2008, Swedish employers organized within SN did argue and lobby about a deregulation of Sweden's state-coordinated labor migration policy. Instead SN preferred the introduction of a market-liberal approach to labor migration (cf. Bucken-Knapp, 2007: 10).

In December 2001, Bijan Fahimi, a board member of SN and a politician in the Liberal Party, authored the SN report Globalisering och arbetsmarknad: Öppna den svenska arbetsmarknaden [Globalization and the Labor Market: Open the Swedish Labor Market]. According to Fahimi, labor migration was an important policy solution to the demographic problems and a recipe to secure Sweden's economic and welfare progress in the future.

However, Fahimi's proposal about increased possibilities concerning non-EU labor migration to the Swedish labor market also contained a critique of the current administrative practices in which local labor market boards played an influential role with regard to both decisions about work permit approvals and decisions when non-EU labor migration should be considered justified or not in relation to the labor market situation. Fahimi wanted to end the state-coordinated labor migration policy, and instead he argued that firms were best suited to decide which type of competence they wanted to recruit (Fahimi, 2001: 16: cf. Bucken-Knapp, 2009: 63).

Another feature of Fahimi's report was that he broached the issue of restrictive benefits policy for migrants. Regarding migrants' access to the Swedish welfare system he suggested: "After a period of time in the Swedish society, certainly, even immigrants should have the right to employ the Swedish welfare system in case of he or she becomes unemployed, but not in the initial phase" (Fahimi, 2001: 16). Fahimi's preferences for a restrictive benefits policy for newly arrived immigrants were controversial as this was at odds with the current welfare state regime of universalism in Sweden. In Sweden migrants' welfare state rights are "bestowed in conjunction with entry," and migrants are granted access to welfare state services and rights provided to citizens and long-term residents (Bucken-Knapp, 2009: 43). The Swedish and Scandinavian welfare states combine a universal income protection and access to a wide range of public welfare state services, with social insurance benefits that are graduated according to accustomed earnings (Esping-Andersen, 1990: 28; Kvist et al., 2012: 5-6). As such, Fahimi’s suggestions challenged both the current state-coordinated labor migration policy and the principle of universalism which has been fundamental to the Swedish and Scandinavian welfare states (cf. Bucken-Knapp, 2009: 37, 69-70).

However, according to Fahimi his proposals regarding a restrictive benefits policy were not reviewed critically within SN. The features concerning migrants' social rights in his report were hardly given any attention at all within SN which he interprets as an acceptance from the organization (Author interview with Bijan Fahimi, March 28, 2012). 
Another SN report, Invandring för tillväxt och nya jobb [Immigration for growth and new jobs], authored by two SN officials, Karin Ekenger and Fabian Wallen, and published in July the following year, 2002, contained a more detailed proposal suggesting a radical reform of Swedish labor migration policy in a market-liberal direction. Like Fahimi, Ekenger and Wallen (2002) proposed a revision of Swedish labor migration policy in which assessment procedures of local labor market boards about the need for labor and the involvement of trade unions in the assessment of work permits were to be abolished. Ekenger and Wallen (2002: 20) instead preferred a system where the individual employer fully was to decide and assess of their labor recruiting needs.

Other reports from SN (Paues, 2003; SN, 2006) underscored the employer organizations' interest to deregulate labor migration policy in a way that would increase the influence of employers in decisions about recruitment of migrant workers and decisions about work permits at the expense of the previous influence by trade unions and labor market authorities. SN's policy preferences was driven by an employer interest to increase employers' possibilities of steering and controlling the supply of labor in relation to state authorities and trade unions (cf. Bucken-Knapp, 2009: 66-67; Svanberg, 2011: 105-107).

\section{SN's views about labor migration and welfare state challenges}

In the SN reports, the employer organizations' views regarding the relationship between migration and welfare state challenges can be identified. Ekenger and Wallen (2002: 14-15) referred to figures of increased labor recruiting needs in the private sectors of engineering, construction, transportation, and restaurants and in the public sectors of health care and social services due to increased numbers of retirements. Besides this, they presented data of the demographic development with an ageing population, and decreasing numbers of people in working ages. Against the backdrop of the statistical pictures presented, Ekenger and Wallen argued for labor migration as a crucial policy solution to these structural problems of the welfare state. Moreover, Fahimi (2001), Ekenger and Wallen (2002), as well as Paues (2003) emphasized connections between labor migration, working rates, firm competitiveness, and welfare state services. Ekenger and Wallen underscored these connections:

\footnotetext{
Already in the present situation it is important for us to open up a possibility for people who want to come here to work. At the same time we have to remove obstacles to be able to take better care of unutilized resources in Sweden. We need more people at work otherwise companies will not be able to establish or expand in Sweden, simultaneously we will not afford decent public welfare services. (Ekenger \& Wallen, 2002: 16)
}

Similar argumentation about the need for labor migration as a policy solution to labor shortages, in addition to measures aiming at improving workforce participation among different marginalized groups already residing in Sweden, was presented in SN's response (2007) to a state-commissioned inquiry (SOU 2006: 87) and a governmental proposal regarding reform of the rules governing non-EU labor migration (Ds 2007: 27). Labor shortages and the demographic development were also pointed out as challenges to growth by $\mathrm{SN}$ in the response: 
Despite relatively high unemployment, we already have a rapidly increasing shortage of labor in several professions, sectors and regions. [...] It is obvious that the difficulties in finding competent and skilled co-workers imply a challenge to growth. For several years ahead, the demographic development, with a shrinking workforce, an ageing population and an excessive rise in the old-age dependency ratio, will exacerbate these problems, especially in sparsely-populated rural districts. (SN, 2007)

For SN market-liberal labor migration reform represents an important policy solution in the effort to maintain and expand levels of economic growth and firm competitiveness, as well as to ensure that the generous welfare state services associated with Swedish society are both funded and staffed as the 1940s generation exits the workforce in ever larger numbers (cf. Bucken-Knapp, 2007: 1).

\section{SN and social benefits policy}

Social issues in general and social and integration policies toward newly arrived immigrants specifically were topics not given much attention at all in the SN reports concerning labor migration. Yet, unlike Fahimi (2001), Ekenger and Wallen (2002) did not authorize a restrictive benefits policy that would give migrants access to the Swedish welfare system after a period of time in Sweden. However, Ekenger and Wallen proposed that non-EU citizens would be allowed to stay in Sweden for a period of three months to conduct a job search. During that initial period, the job-searching migrant had to be able to support him/herself, and would not be entitled to social benefits. Yet, when starting to work in Sweden, migrants would receive access to and contribute to the financing of the Swedish social insurance system at the same way as all others working and residing in Sweden (Ekenger \& Wallen, 2002: 27; cf. Bucken-Knapp, 2009: 69).

Moreover, despite Fahimi's later statements (author interview with Bijan Fahimi, March 28, 2012) that his proposals concerning a restrictive benefits policy were not controversial within $\mathrm{SN}$, the $\mathrm{SN}$ officials were conscious of the fact that migrant access to generous welfare state services and benefits was a sensitive issue (author interview with Karin Ekenger, March 27, 2012; cf. Bucken-Knapp, 2009: 69). In Ekenger and Wallen's report, the authors discussed the potential impacts of liberalized labor migration on the Swedish welfare system. Ekenger and Wallen argued against statements that labor migration would increase economic costs in relation to the welfare state:

Sometimes it is declared that labor migration would affect and increase the costs upon our welfare system, however the fact is that labor migration has positive effects for the welfare system. When more people work, earn money and pay taxes, there are increased possibilities to maintain generous levels within the safety system. Furthermore, the social insurance system is also constructed in a way that there is no risk of over-exploitation. (Ekenger \& Wallen, 2002: 26; A shorter translated quote from Ekenger and Wallen's report in BuckenKnapp, 2009: 69)

In Ekenger and Wallen's report, as in the other analyzed SN reports and proposals, SN frequently stressed the importance of work as an important criterion regarding both the production and the allocation of welfare state benefits and services. Fahimi's 
preferences for a system where the individual's work, and not entry or residence, should be the criterion for where appropriate boundary lines ought to be drawn regarding migrants' welfare state rights could likely be explained in relation to this work-centered discourse within SN.

Nevertheless, in the SN proposal by Ekenger and Wallen, the restrictive benefits policy was absent, in contrast to Fahimi's report. According to Karin Ekenger, the issue of a qualification period for non-EU labor migrants concerning welfare state rights was Fahimi's personal views, and not the official views of SN (author interview with Karin Ekenger, March 27, 2012). Thus, a remark from the two author interviews is that the views differ between Fahimi and Ekenger about SN's standpoints regarding Fahimi's proposal on this specific issue. Nevertheless, an awareness among SN officials that the restrictive benefits policy was politically sensitive, and at odds with the leading principle of universalism in Swedish social policy, likely influenced SN to remove this feature of its detailed policy proposals to overhaul state-coordinated labor migration policy (cf. Bucken-Knapp, 2009: 69). Instead, SN has continued to officially support a generous benefits policy.

\section{LO's preferences for state-coordinated labor migration policy and generous benefits policy}

Disagreements between the social partners about how an increased labor migration would be organized became more obvious when LO published a package of reports, presenting its labor migration policy preferences.

In 2003, LO published the report Flytt, pendling, arbetskraftsinvandring och europeisk integration [Movements, commuting, labor migration and European integration] authored by LO economists Dan Andersson and Thord Pettersson. The authors described a future challenging situation with an ageing population, and argued for a need to increase the number of working hours substantially, by getting more people in work, reducing the number of early retirements, striving to get more people to work past the age of 65 , stimulating economic growth and childbirth rates, and increasing the effectiveness of the education system to reduce the amount of time spent in school (Andersson \& Pettersson, 2003: 38-39). These work-centered arguments from LO's economists in many ways correlated with SN's preferences about these specific issues. The interests of SN and LO coincided in this respect.

The authors also used previous historical experiences of labor migration in Sweden during the 1960s and the trade union critique from that time as a shield of evidence, in arguing against a deregulated labor migration policy. The experiences of the 1960s, which was a period of "tourist immigration" as LO described it, which meant that foreign citizens easily could come to Sweden on tourist visas and search for employment on-site, was now used by LO as a threatening image of what could be expected if the employers and bourgeois parties were able to reform the labor migration policy in a pure market-liberal direction (Andersson \& Pettersson, 2003: 31-33; cf. Bucken-Knapp, 2009: 97-98).

As Bucken-Knapp (2009: 98) argues, LO's message during the 2000s policy debate was that a resumption of deregulated labor migration in the 2000s would lead to the same problems as experienced during the 1960s. Andersson and Pettersson also stressed 
in the report: "In 1968 the Swedish parliament realized that the system of free labor migration was no longer justified. That conclusion is the only reasonable one, even today" (Andersson \& Pettersson, 2003: 33). As a consequence of this reasoning, Andersson and Pettersson presented following LO policy proposals regarding the organization of labor migration from non-EU countries:

Labor migration should increase but also be more regulated; New and better adjusted channels to labor migration needed to be created and involve cooperation between trade unions and employers; AMS should be assigned a "special mission in supporting labor migration trough the establishment of labor market exchange offices" or "other planned efforts to be located in non-EU countries"; Migrants should be "offered open-ended job contracts, housing and Swedish language training on the spot, with some role in this process being given to AMS"; Labor migrants should have the same wages and working conditions as indigenous workers; Increase efforts to prevent illegal labor migration and work on the side of the formal labor market, "with additional resources being channeled to the police, workplace oversight bodies and tax authorities in order to maintain order on the labor market." (Andersson \& Pettersson, 2003: 41; Translated quotes from Andersson and Pettersson's report in Bucken-Knapp, 2009: 98-99)

The content of LO's policy proposal indicates how LO's interest in controlling the labor supply in a significant way influenced its policy preferences for a regulated labor migration policy. LO was not willing to let migrant workers over the Swedish borders, if the labor market conditions were not in order and in favor of their entrance. By recalling Åmark's (1986) argument that trade unions use restrictive practices to limit the supply of labor and to avoid wage dumping, LO's policy preferences for a regulated labor migration policy may seem logical from a trade union perspective.

LO's opposition to employer proposals concerning liberalized entrance rules, which would facilitate non-EU migrant workers' possibilities to enter Sweden and search for a job on-site in Sweden, was also affected by LO's interest to protect the welfare state in different respects. As described by Freeman (1986: 57-62) and BuckenKnapp (2009: 35-37, 100), scenarios consisting of liberal immigration rules and large flexibility concerning labor laws and employer's opportunities to hire and fire migrant workers without a need to take broader labor market fluctuations into account may lead to the potential effect of increased financial pressure being placed upon the welfare state, especially since migrant workers in these situations often become dependent on welfare state services to support themselves in cases of unemployment. Thus, LO is also a defender of universal welfare state principals, and an opponent of restrictive benefits policies for migrants (LO, 2004, 2006). Accordingly, I agree with BuckenKnapp emphasizing that LO's demand for AMS involvement in determining whether there are labor shortages or not, and the requirement that migrants should be offered open-ended employment contracts, housing, and Swedish language training, making dismissal more difficult for employers, could be seen as measures decreasing the likelihood that migrant workers immigrating to Sweden will become unemployed (BuckenKnapp, 2009: 100, 151). By preferring a regulated immigration policy combined with strong control measures concerning the entrance of labor migrants as required by labor market fluctuations, LO minimizes the risks of unemployed migrants putting financial pressure on welfare state services. 


\section{LO's views about labor migration and welfare state challenges}

Moreover, LO has expressed reservations in opposition to employer images concerning labor migration as the most important policy solution to Sweden's demographic challenge. The LO report Mer än bara öppna gränser [More than just open borders] published in 2004 presented figures of the enormous quantity of immigration that would be necessary if Sweden were to use only labor migration as a strategy to prevent the negative effects of increased numbers of pensioners (LO, 2004: 11). Furthermore, in another report, Migration och arbetsmarknad [Migration and Labor Market] published in June 2006, LO painted a picture where unequal competitiveness, social dumping, and decreased levels of costs would have a negative impact on the welfare state in case of a deregulated labor market (LO, 2006: 13-16). If Swedish companies had to compete under unequal conditions and decrease levels of profits and costs, the employees' wages would also decrease within these companies as a consequence. Moreover, poor wage development for wage earners would also have a negative impact on state tax prospects, which probably would entail limitations in societal welfare state services afforded to Swedish citizens and residents. Hence, LO concluded this reasoning by stressing that there were clear connections between a regulated labor migration policy and the existence of equal conditions between companies and between indigenous and migrant workers associated with collective bargaining agreements. LO emphasized that such a system was a guarantee of a prosperous Swedish welfare state (LO, 2006: 16).

Generally, from LO's point of view a regulated and state-coordinated labor migration policy combined with a generous benefits policy will neutralize potential threats to important union interests. By regulating the labor supply and by granting labor migrants permanent residency, full labor market access, and full access to welfare state services, such policy measures minimize potential negative effects of labor migration for the functioning of the Swedish labor market model and the welfare state (cf. Bucken-Knapp, 2009: 100, 112, 151).

\section{Conclusions and Discussion}

The empirical findings demonstrate that the Swedish employer organization SAF, during the 1960s, and its organizational successor SN, during the 2000s, have had preferences for a market-liberal labor migration policy. Over time, liberal immigration policy concerning labor migration has been viewed by employers as an important policy solution to offset labor shortages and secure a suitable skilled workforce to be able to consequently maintain and extend levels of economic growth and firm competitiveness, which represents basic employer interests. Moreover, there has been continuity regarding the employers' views about the positive effects of labor migration for the welfare state. According to employers, immigrants foremost contribute to economic growth and public revenue through their work and tax payments. By these positive economic effects labor migration will generate increased possibilities to maintain funding for generous welfare state services.

Continuity also characterize LO's policy preferences concerning labor migration. Since the 1960s LO has preferred a state-coordinated and regulated labor migration policy. Its stances reflect what Banting (2000) has referred to as a "welfare chauvinistic" 
view of the nexus between migration and the welfare state. Thus, LO's preferences for restrictive immigration policy also reflects basic trade union interests to control the labor supply and avoid the risk of wage dumping.

There are similarities between the 1960s debate and the 2000s debate when it comes to trade union concern about the risks of wage dumping and worsening working conditions as a consequence of unregulated labor migration. A common theme in the trade union argumentation during the different time periods is the vulnerability of the workers and residents already in Sweden. Regulated labor migration has been presented as a prerequisite to secure decent wages and working conditions for indigenous Swedes and immigrants already working and residing in Sweden (cf. Spång, 2009: 81).

Labor market conditions have close connections with integration issues and universal welfare state ambitions. For LO a restrictive immigration policy has been seen as a precondition for realizing universal welfare state ambitions. During the 1960s a regulated immigration policy was presented by LO as a necessary prerequisite for the potential of Swedish society to take good care of immigrants and give them equal social conditions as indigenous Swedes regarding employment, housing, and social benefits. However, in later debates about labor migration, the theme about migrants exploiting or putting a financial pressure on the welfare state has become a much more contested issue than it was in the 1960s debate (cf. Spång, 2009: 106). Thus, SN has argued against claims of increased risks of migrant exploitation of the welfare state. Nevertheless, in LO's perspective the potential risks of migrants putting a financial pressure on welfare state services are minimized through a regulated and state-coordinated policy regarding migrants' entry as well as employment and working conditions (cf. Bucken-Knapp, 2009: 100, 112).

LO views labor migration as one factor that could be important within a broader battery of measures to increase the number of working hours substantially. According to $\mathrm{LO}$, however, a regulated labor migration policy is a fundamental precondition for guaranteeing workers' rights, and for minimizing potential negative effects for the functioning of the Swedish labor market model and for a prosperous Swedish welfare state (cf. Bucken-Knapp, 2009: 104, 151-152).

Regarding the question to what degree new labor migrants would gain access to welfare state services and rights, SAF, SN, and LO have officially supported a generous benefits policy throughout the two studied periods. However, neither SAF during the 1960s nor SN during the 2000s have given much attention to social and integration policies toward newly arrived immigrants in their policy proposals concerning labor migration. For LO, on the other hand, the principle of universalism in social policy has been central, and LO has supported labor migrants' access to welfare state services and rights on a par with that of citizens and long-term residents (cf. Bucken-Knapp, 2009: 100, 104).

Concerning the influence of the social partners in labor migration policymaking, the driving role has shifted over time. In the earlier context policy formation and decisions were made in a corporatist institutional structure, and rather often did not include the parliament (cf. Spång, 2009: 106). LO influenced other central actors like SAP and AMS and in many ways drove the reformation process of Swedish immigration policy concerning regulation of the non-Nordic labor immigration in the late 1960s and early 1970s. Even if employers and trade unions still are important and influential actors in discussions and decisions, there has been a gradual shift in this policy area away from corporatist arrangements. In general, parliament since the late 1980s and until today has become a more important arena for debate and policymaking compared to the situation 
during the 1960s (cf. Lindvall \& Sebring, 2006; Spång, 2009: 106). Furthermore, Sweden's EU membership since 1994 and the trend of increased Europeanization are international factors of enlarged importance in relation to migration policymaking (Hansen, 2008; Spång, 2007, 2009).

Yet, another important difference between the 1960s and 2000s is that LO and the trade unions have lost much of their previous influence in this policy area. Instead the employers' views have gained more influence. SN's proposals to increase employers' mandate to decide in decisions about recruitment of migrant workers and decisions about work permits at the expense of the previous influence of trade unions and labor market boards, as well as the decision by the bourgeois government in late 2008 to implement a new policy for labor migration from non-EU countries, in which assessment procedures was to be done by employers and not include labor market authorities and trade unions, were important events, which marks an important shift in this area of policymaking (Bucken-Knapp, 2009: 155; Spång, 2009: 90-92). Besides, the shift of influence between the social partners in Swedish labor migration policymaking reflects general changes and the shifting power of employers and trade unions in advanced capitalist economies.

To sum up, the Swedish case of labor migration policy debates between organized interests of employers (SAF and SN) and trade unions (LO) clearly supports Freeman's political economy perspective arguing that migration policymaking is about defending interests (cf. Freeman, 1986, 2004). In two different historical contexts the Swedish social partners have mobilized and participated in labor migration policy debates and policymaking to prevent the implementation of policies considered to being destructive to their perceived collective interests on the labor market and in relation to the welfare state (cf. Bucken-Knapp, 2009: 157; Freeman, 2004: 117-118).

\section{References}

Andersson, D. \& Pettersson, T. (2003). Flytt, pendling, arbetskraftsinvandring och europeisk integration. Stockholm: Landsorganisationen (LO) [Movements, commuting, labor migration and European integration].

Author interview with Karin Ekenger, adviser at the Swedish Confederation of Enterprise (SN), March 28, 2012.

Author interview with Bijan Fahimi, managing director at Veritas PR \& Communications AB, Stockholm, board member of Swedish Confederation of Enterprise (SN), March 29, 2012.

Banting, K. (2000). 'Looking in three directions. Migration and the European welfare state in comparative perspective'. In M. Bommes \& A. Geddes (eds.). Immigration and Welfare. Challenging the borders of the welfare state, pp. 13-33. London and New York: Routledge.

Boräng, F. (2012). National Institutions-International Migration. Labour Markets, Welfare States and Immigration Policy. Göteborg: Göteborg Studies in Politics 129.

Bucken-Knapp, G. (2009). Defending the Swedish Model. Social Democrats, Trade Unions, and Labor Migration Policy Reform. Lanham, MD: Lexington Books.

Bucken-Knapp, G. (2007). 'Varieties of Capitalism and Labor Migration Policy'. Preprint/ Högskolan Väst 1653-4603; 2007: 01.

Cavidies, A. (2010). Prying Open Fortress Europe: the Turn to Sectoral Labor Migration. Lanham, MD: Lexington Books. 
Ds 2007: 27. Ett effektivt och flexibelt system för arbetskraftsinvandring. Stockholm: Justitiedepartementet [An efficient and flexible system of labor immigration].

Dølvik, J. E. \& Eldring, L. (2008). Arbeidsmobilitet fra de nye EU-landene til Nordenutviklingstrekk og konsekvenser. TemaNord 2008: 502, Slutrapport fra en nordisk arbejdsgruppe under Nordisk Ministerråd, København: Nordisk Ministerråd [Labor mobility from the new EU-countries to the Nordic region-development trends and consequences].

Ekenger, K. \& Wallen, F. (2002). Invandring för tillväxt och nya jobb. Stockholm: Svenskt Näringsliv (SN) [Immigration for growth and new jobs].

Esping-Andersen, G. (1990). The Three Worlds of Welfare Capitalism. Cambridge: Polity Press.

Fahimi, B. (2001). Globalisering och arbetsmarknad. Öppna den svenska arbetsmarknaden. Stockholm: Svenskt Näringsliv (SN) [Globalization and the Labor Market: Open the Swedish Labor Market].

Frank, D. (2005). Staten, företagen och arbetskraftsinvandringen: en studie av invandringspolitiken i Sverige och rekryteringen av utländska arbetare 1960-1972. Växjö: Växjö University Press [The state, companies and labor immigration: a study of immigration policy in Sweden and the recruitment of foreign workers 1960-1972].

Freeman, G. P. (1986). 'Migration and the Political Economy of the Welfare State'. Annals of the American Academy of Political and Social Science, 485: 51-63.

Freeman, G. P. (2004). 'Political Science and Comparative Immigration Politics'. In M. Bommes \& E. Morawska (eds). International Migration Research. Constructions, Omissions and the Promises of Interdisciplinarity, pp. 111-128. Aldershot: Ashgate.

Hammar, T. (1988). 'Mellan rasism och reglering. Invandringspolitikens ideologi och historia', Arbetarhistoria Nr. 46: 11-14 [Between racism and regulation. The ideology and history of immigration policy].

Hansen, P. (2008). EU:s migrationspolitik under 50 år. Ett integrerat perspektiv på en motsägelsefull utveckling. Lund: Studentlitteratur [The migration policy of the EU during 50 years. An integrated perspective on a development full of contradictions].

Hermansson, J. (1993). Politik som intressekamp. Stockholm: Norstedts Juridik [Politics as struggle of interests].

Hermansson, J., Lund, A., Svensson, T., \& Öberg, P-O. (1999). Avkorporatisering och lobbyism. in SOU 1999: 121, Stockholm: SNS Förlag [Decorporatization and lobbyism].

Johansson, J. (2008). 'Så gör vi inte här i Sverige. Vi brukar göra så här'. Retorik och praktik i LO:s invandrarpolitik 1945-1981. Växjö: Växjö University Press ['We actually don't do like that here in Sweden. We usually do like this'. Rhetoric and Practices in LO's immigration policy 1945-1981].

Johansson, J. (2013). 'Union solidarity in exchange for adaptation. Immigration policy and the Swedish Trade Union Confederation from the 1960s to the early 1980s'. In M. Byström and P. Frohnert (eds.). Reaching a State of Hope. Refugees, Immigrants and the Swedish Welfare State, 1930-2000, pp. 235-254. Lund: Nordic Academic Press.

Knocke, W. (2000). 'Sweden: Insiders Outside the Trade Union Mainstream'. In R. Penninx and J. Roosblad (eds). Trade Unions, Immigration and Immigrants in Europe 1960-1993. A Comparative Study of the Attitudes and Actions of Trade Unions in Seven West European Countries, pp. 157-182. New York and Oxford: Berghahn Books.

Kvist, J., Fritzell, J., Hvinden, B., \& Kangas, O. (2012) 'Changing social inequality and the Nordic welfare model’. In J. Kvist, J. Fritzell, B. Hvinden \& O. Kangas (eds.). Changing Social Equality. The Nordic Welfare Model in the 21 $1^{\text {st }}$ Century, pp. 1-22. Bristol: The Policy Press.

Kyle, G. (1979). Gästarbeterska i manssambället. Studier om industriarbetande kvinnors villkor i Sverige. Stockholm: Liberförlag [Female guest worker in man's society. Studies about the conditions of industrial working women in Sweden]. 
Landsorganisationen (LO) (2004). Mer än bara öppna gränser. Stockholm: LO [More than just open borders].

Landsorganisationen (LO) (2006). Migration och arbetsmarknad. Stockholm: LO [Migration and labor market].

Lewin, L. (1992). Sambället och de organiserade intressena. Stockholm: Nordstedts Juridik [Society and the organized interests].

Lindvall, J. \& Sebring, J. (2006). 'Policy Reform and the Decline of Corporatism in Sweden', West European Politics 28(5): 1057-1074.

Lundh, C. (1994). 'Invandrarna i den svenska modellen—hot eller reserv? Fackligt program på 1960-talet', Arbetarhistoria Nr. 70: 23-36 [The immigrants in the Swedish Modelthreat or reserve? Trade union program in the 1960s].

Lundqvist, T. (2002). 'Arbetskraftsinvandring och facket. Debatt och historia i ett framtidsperspektiv'. In B. Malmberg \& L. Sommestad (eds.). Befolkning och välfärd. Perspektiv på framtidens välfärdspolitik, pp. 107-139, Stockholm: LO \& Institutet för framtidsstudier [Labor immigration and unions. Debate and history in a future perspective].

Lundqvist, T. (2006). 'Labour Migration and Organized Interests: The Swedish Model'. In K. Tamas \& J. Palme (eds.). Globalizing Migration Regimes. New Challenges to Transnational Cooperation, pp. 185-200. Aldershot: Ashgate.

Menz, G. (2008). The Political Economy of Managed Migration. Oxford: Oxford University Press.

Nelhans, J. (1973). Utlänningen på arbetsmarknaden. De rättsliga förutsättningarna för utlänningars tillträde till den svenska arbetsmarknaden. Lund: Studentlitteratur [The foreigner on the labor market. The legal conditions regarding foreigner's admission to the Swedish labor market].

Paues, T. (2003). Arbetskraftsinvandring ett år senare. Stockholm: Svenskt Näringsliv (SN) [Labor immigration-one year later].

Penninx, R. \& Roosblad, J. (2000) (eds). Trade Unions, Immigration and Immigrants in Europe 1960-1993. A Comparative Study of the Attitudes and Actions of Trade Unions in Seven West European Countries. New York and Oxford: Berghahn Books.

Regeringens proposition, 1968: 142 [Government proposition].

Regeringens proposition, 2007/08: 147 [Government proposition].

Riksdagens protokoll, 2008/09: 26 [Parliament record].

SOU 1967: 18. Invandringen. Problematik och handläggning. Utlänningsutredningens betänkande II. Stockholm [Immigration. Problems and handling. Report II of the Foreigner Commission].

SOU 2005: 50. Arbetskraftsinvandring till Sverige-befolkningsutveckling, arbetsmarknad i förändring, internationell utblick. Kommittén för arbetskraftsinvandring (KAKI), Stockholm [Labor immigration to Sweden-population development, changing labor market, international outlook. Committee on Labor Immigration].

SOU 2006: 87. Arbetskraftsinvandring till Sverige-förslag och konsekvenser. Kommittén för arbetskraftsinvandring (KAKI), Stockholm [Labor immigration to Sweden-proposals and consequences. Committee on Labor Immigration].

Spång, M. (2007). 'Sweden: Europeanization of Policy but not of Politics?’ In T. Faist \& A. Ette (eds.). The Europeanization of National Policies and Politics of Immigration. Between Autonomy and the European Union, pp. 116-135. London: Palgrave.

Spång, M. (2009). 'Debating Labor Immigration and Immigration Policy in Sweden, 1960-2008’. In S. Mayer \& M. Spång (eds). Debating Migration. Political Discourses on Labor Immigration in Historical Perspective, pp. 74-106. Innsbruck: StudienVerlag.

Svanberg, J. (2010). Arbetets relationer och etniska dimensioner. Verkstadsföreningen, Metall och esterna vid Svenska Stålpressnings AB i Olofström 1945-1952. Växjö: Linnaeus University Press [Labor relations and ethnic dimensions of work. The Swedish Engineering 
Employers' Association, the Swedish Metalworkers' Union and the Estonians at Svenska Stålpressings AB in Olofström 1945-1952].

Svanberg, J (2011). 'Labour Migration and the Swedish Labour Market Model. A Case Study of Recruitment of Yugoslav Workers to Svenska Fläktfabriken in Växjö, 1969-1970’. Scandinavian Journal of History 36(1): 91-113.

Svenskt Näringsliv (SN) (2006). Företagen—inte AMS—avgör bäst behoven av nyanställningar, 2 June [Companies—not the Labor Market Board (AMS)—are best suited to determine the need of recruitments].

Svenskt Näringsliv (SN) (2007). Remissyttrande angående betänkandet "Arbetskraftsinvandring till Sverige-förslag och konsekvenser (SOU 2006: 87)" samt över departementsskrivelsen "Ett effektivt och flexibelt system för arbetskraftsinvandring (Ds 2007: 27)". 15 November [Consultation response concerning Committee report 'Labor immigration to Sweden-proposals and consequences' and on the ministry report 'An efficient and flexible system of labor immigration'].

Thompson, J. B. (1984). Studies in the Theory of Ideology. Cambridge: Polity Press.

Waara, J. (2012). Svenska Arbetsgivareföreningen och arbetskraftsinvandringen 1945-1972. Göteborg: Gothenburg Studies in Economic History 7 [The Swedish Employers' Confederation and labor immigration 1945-1972].

Williamson, P. J. (1989). Corporatism in Perspective: An Introductory Guide to Corporatist Theory. London: Sage.

Yalcin, Z. (2010). Facklig gränspolitik. Landsorganisationens invandrings-och invandrarpolitik 1946-2009. Örebro: Örebro Studies in History 10 \& Örebro Studies in Conditions of Democracy 4 [Trade Union Boundary Politics-The Swedish Trade Union Confederation's immigration policy 1946-2009].

Åmark, K. (1986). Facklig makt och fackligt medlemskap. De svenska fackförbundens medlemsutveckling 1890-1940. Lund: Arkiv förlag [Trade union power and trade union membership. The Swedish National Trade Unions' membership development 1890-1940].

Åmark, K. (1992). 'Sweden'. In J. Campell (ed.). European Labour Unions, pp. 427-440. New York: Greenwood Press.

\section{End notes}

${ }^{1}$ Sweden has been a member of the EU since 1994, and intra-EU migration is free. In Sweden the proportions of different forms of intra-EU labor migration have been smaller than policymakers and experts have expected before different waves of EU enlargements in the 1990s and the 2000s (Dølvik \& Eldring, 2008).

${ }^{2}$ According to the 1954 agreement on a common Nordic labor market, citizens from the other Nordic countries had the right to free movement for work and settlement in Sweden. In practice, since 1943 citizens from the Nordic countries had been exempted from the requirement of a work permit by the Swedish authorities.

${ }^{3}$ Due to the 1954 agreement on a common Nordic labor market, the trade union movement as a consequence had no influence over the conditions surrounding immigration of citizens from the other Nordic countries.

${ }^{4}$ Collective state recruitment of migrant workers via labor market authorities had earlier been used during late 1940s and early 1950s. However, this recruiting approach was little used and only small numbers of migrant workers came to Sweden through these recruitment procedures. The most significant examples were probably the recruitment of Italians and Hungarians in 1947 and different cohorts of Estonians and Germans in the early 1950s (Lundqvist, 2002; Svanberg, 2010). 